\title{
Comparison of Types and Size of Biomass on Pirolysis Combustion Toward The Results of Bio- Charcoal and Liquid Smoke
}

\author{
Kemas Ridhuan ${ }^{1 *}$, Dwi $\operatorname{Irawan}^{2}$, Rahmady Setiawan ${ }^{3}$ \\ 1,2,3 Mechanical Engineering Study Program, Muhammadiyah University of Metro \\ Jl. Ki Hajar Dewantara 15 A Iring Mulyo \\ *Email: kmsridhuan@yahoo.co.id
}

\begin{tabular}{|c|c|}
\hline Article Information: & Abstract \\
\hline $\begin{array}{l}\text { Received: } \\
12 \text { March } 2020\end{array}$ & $\begin{array}{l}\text { Biomass is a renewable carbon source and can be processed into gas fuels, } \\
\text { liquid and solid fuels. Biomass has several types with different grain sizes. } \\
\text { Biomass can be converted to other forms of energy by combustion pyrolysis. }\end{array}$ \\
\hline $\begin{array}{l}\text { Received in revised form: } \\
2 \text { May } 2020\end{array}$ & $\begin{array}{l}\text { Pyrolysis is the chemical decomposition of organic matter through a heating } \\
\text { process at high temperatures with little or no oxygen. The results of the } \\
\text { pyrolysis process in the form of bio-charcoal and liquid smoke. The purpose }\end{array}$ \\
\hline $\begin{array}{l}\text { Accepted: } \\
5 \text { May } 2020\end{array}$ & $\begin{array}{l}\text { of this research was to determine the comparison of types and sizes of biomass } \\
\text { in pyrolysis combustion with characteristics of bio-charcoal and liquid smoke. } \\
\text { This research method uses rubber shell biomass waste, green coconut husk } \\
\text { and rice husk. Biomass is burned by slow pyrolysis in the reactor with biomass }\end{array}$ \\
\hline $\begin{array}{l}\text { Volume } 2 \text {, Issue } 1 \text {, June } 2020 \\
\text { pp. } 10-15\end{array}$ & $\begin{array}{l}\text { fuel. Combustion in reactors and pitot tubes containing biomass. Measured } \\
\text { temperature, time, amount of biomass, bio-charcoal and liquid smoke and the } \\
\text { heating value of bio-charcoal. The research results obtained the heating value }\end{array}$ \\
\hline (C) Universitas Lampung & $\begin{array}{l}\text { of rubber shell bio-charcoal at } 6661.55 \mathrm{cal} / \mathrm{gr} \text {, bio-charcoal yield of } 2.3 \mathrm{~kg} \text {, } \\
\text { liquid smoke yield of } 0.242 \mathrm{~kg} \text {, green coconut husk biomass heating value }\end{array}$ \\
\hline http://dx.doi.org/10.23960/jesr.v2i1.37 & $\begin{array}{l}\text { amounted to } 5388.56 \mathrm{cal} / \mathrm{gr} \text {, the yield of } 1.8 \mathrm{~kg} \text { of bio-charcoal, the result of } \\
\text { liquid smoke of } 0.308 \mathrm{~kg} \text { and rice husk biomass obtained the heating value of } \\
3626.48 \mathrm{cal} / \mathrm{gr} \text { with a bio-charcoal yield of } 1.3 \mathrm{~kg} \text { resulting from liquid smoke } \\
\text { of } 0.284 \mathrm{~kg} \text {. }\end{array}$ \\
\hline
\end{tabular}

Keywords: Combustion, Pyrolysis, Liquid Smoke, Charcoal, Biomass

\section{INTRODUCTION}

As a fuel, biomass needs to be processed first so that it can be more easily used, known as biomass conversion. Biomass conversion technology requires differences in the tools used to convert biomass and produce fuel differences produced [1]. Utilization of biomass as an energy source can be processed by pyrolysis combustion. Pyrolysis combustion is a thermochemical decomposition process of organic matter (biomass) through a heating process using less or no oxygen. Pyrolysis is a process of combining with incomplete combustion of materials containing carbon at high temperatures [2]. Pyrolysis process is defined as the thermal degradation of solid material (biomass) under limited air/oxygen conditions and from this process gas, tar and char are generated [3]. Scientifically, pyrolysis is the process of thermal decomposition of organic matter at temperatures around $350^{\circ} \mathrm{C}-550^{\circ} \mathrm{C}$ without oxygen. This process releases 3 types of products, namely liquid (Bio-oil), solid (charcoal), and gas $(\mathrm{CO}, \mathrm{CO} 2, \mathrm{H} 2, \mathrm{H} 2 \mathrm{O}$, and CH4) [4].

Pyrolysis combustion results in form of charcoal (char), oil and gas are useful outcome. The charcoal produced is activated charcoal, which is a fuel that has a high heating value or is used as activated carbon. Activated carbon is known as a promising material with a wide application as an adsorbent, catalyst or carrier catalyst due to its good surface and texture characteristics, which can be easily controlled [5]. Biooil or liquid smokes produced can be used as additives or mixtures in fuel or can also be a food preservative or certain products. Liquid smokes are a result of distillation or condensation of steam from indirect or direct combustion from materials that contain a lot of carbon and other compounds [6].

Liquid smokes are a blend solution of the colloidal dispersion of wood smokes in water, the result of condensation which contains a number of compounds 
formed by pyrolysis of wood constituents such as cellulose, hemicellulose, and lignin. That during the pyrolysis process cellulose compounds will produce carbonyl and acetic acid and their homologies, while from lignin compounds will produce phenols and tar [7][8][9]. Furthermore, hemicellulose compounds will produce furfural, furan, and carboxylic acids.

Pyrolysis combustion uses various biomass-derived from several types of plant sources. Biomass has a characteristic and composition varies depending on the type [10]. Each type of wood or biomass material will produce liquid smokes with a composition of different amounts of compounds. According to Girard (1992), the composition of liquid smokes is affected by various factors, including wood type, wood moisture content and pyrolysis temperature used. Each type of wood has different cellulose, hemicellulose, and lignin contents.

Each type of biomass has a particular grain size and hardness texture and water content levels. This will affect the pyrolysis combustion process and the characteristics of the product obtained. That the larger the particle size, the greater the minimum fluidization speed. Size of the fuel will affect the reactor temperature and the amount of heat produced by the gasification gas where the largest amount of heat is generated by the fuel with a size of $1.54 \mathrm{~mm}$ with the heat generated in the amount of $1870,083 \mathrm{~kJ}$ [12].

Some biomass has different grain sizes or chunks such as rice husks that have lightweight but hard grain sizes, then rubber shells with medium grain shape and hard texture. Furthermore, green coconut husk biomass with large but fibrous and soft chunks with high water content. With these differences will certainly result in different pyrolysis combustion and the results of biocharcoal and liquid smoke with different characteristics. The smaller the biomass grains the bigger the combustion temperature and on the contrary the average temperature in the rice husk reactor size of $1.54 \mathrm{~mm}$ and $1.84 \mathrm{~mm}$ tend to be bigger that is $237^{\circ} \mathrm{C}$ while the rice husk size of $2.17 \mathrm{~mm}$ lower temperature distribution [12].

\section{MATERIALS AND METHODS}

Biomass raw materials used in this research are rubber shell biomass, green coconut husk, and rice husk. Three biomasses were selected due to they have different grain sizes and levels of hardness. Biomass is burned by a slow pyrolysis process in which the combustion temperature is below $400{ }^{\circ} \mathrm{C}$. The amount of biomass used is as much as the volume of a pitot tube. The same biomass fuel as the biomass of the raw material was used. The equipment used is a set of pyrolysis reactor, pyrolysis tube (pitot) and condenser, thermocouple. Condenser uses a spiral pipe with copper Journal of Engineering and Scientific Research (JESR) Vol 2, Issue 1, June 2020 material which is cooled using water. The results generated from the pyrolysis combustion are activated charcoal and liquid smokes.

Testing Procedure is put the biomass material (rubber shell, green coconut husk, and rice husk) into the pitot tube then put it into the reactor and then fuel with the same biomass as the rubber shell after it is burned. Record the results of the temperature measurements at each point for each 15-minute change. Pay attention to the cooling process of the liquid smoke until the droplets come out and wait for the droplets to stop completely and not come out again. When finished, remove the charcoal from the pitot tube, then weigh the mass of the charcoal and the liquid smoke it gets. Test other biomass materials in the same procedure. The biocharcoal is tested in a chemical laboratory to find out the heating value, moisture content and ash content. And liquid smoke contains $\mathrm{pH}$, lignin and acetic acid.

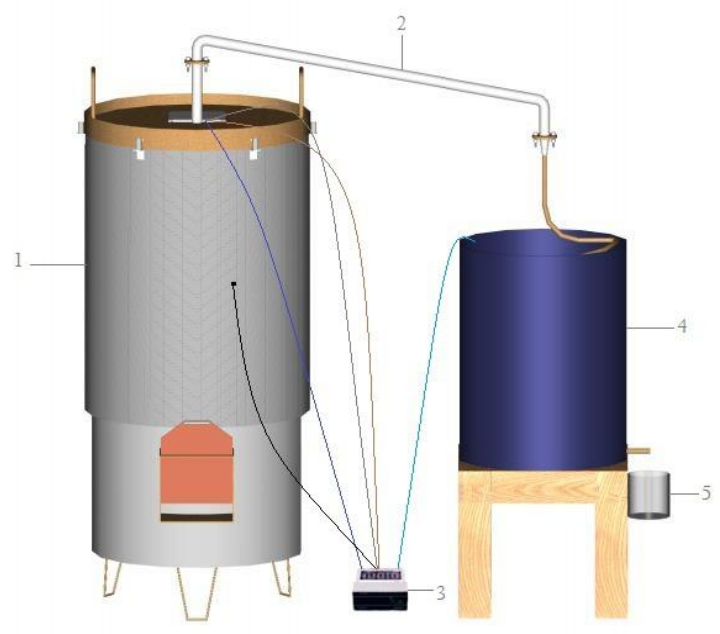

Figure 1. Pyrolysis reactor and condenser circuit

Caption :

1. Pyrolysis reactor,

2. Connecting pipe,

3. Thermocouple,

4. Condenser,

5. Liquid smoke reservoir

\section{RESUlTS AND DISCUSSIONS}

After testing, the data obtained from the pyrolysis process can be obtained by using three raw materials, namely rubber shells, green coconut husks and rice husks namely.

Table 1. Pyrolysis Test Results

\begin{tabular}{|l|l|l|l|}
\hline $\begin{array}{l}\text { Biomass } \\
\text { Material }\end{array}$ & $\begin{array}{l}\text { Rubber } \\
\text { Shell }\end{array}$ & $\begin{array}{l}\text { Green } \\
\text { Coconut } \\
\text { Husk }\end{array}$ & $\begin{array}{l}\text { Rice } \\
\text { Husk }\end{array}$ \\
\hline Temp & 307 & 227 & 219 \\
\hline
\end{tabular}




\begin{tabular}{|l|l|l|l|}
\hline$\left({ }^{\circ} \mathrm{C}\right)$ & & & \\
\hline $\begin{array}{l}\text { Time } \\
\text { (Minute) }\end{array}$ & 270 & 225 & 190 \\
\hline $\begin{array}{l}\text { Initial } \\
\text { Weight } \\
(\mathrm{kg})\end{array}$ & 4,8 & 4,2 & 2,9 \\
\hline $\begin{array}{l}\text { Amount of } \\
\text { Charcoal } \\
(\mathrm{Kg})\end{array}$ & 2,3 & 1,8 & 1,3 \\
\hline $\begin{array}{l}\text { Amount of } \\
\text { liquid smoke } \\
(\mathrm{kg})\end{array}$ & 0,242 & 0,308 & 0,284 \\
\hline $\begin{array}{l}\text { Heating } \\
\text { value(Cal/gr) }\end{array}$ & 6661,55 & 5388,56 & 3626,48 \\
\hline Energy (kJ) & 4126,44 & 4520,88 & 3083,54 \\
\hline
\end{tabular}

Based on the test results in Figure 2, the rubber shell has the highest combustion temperature of $307^{\circ} \mathrm{C}$ and also a long combustion time of 270 minutes, compared with green coconut husk biomass with a temperature of $277^{\circ} \mathrm{C}$ during 190 minutes, and at the rice husk with a temperature of $219^{\circ} \mathrm{C}$ but the time is quite long, 225 minutes. The combustion occurred due to the rubber shell has a hard texture and medium grain and the highest heating value of $6661.55 \mathrm{cal} / \mathrm{gr}$ so that it can produce good combustion. The carbon content is bound to affect the heating value, the higher the carbon content is bound the higher the heating value, because every time there is an oxidation reaction will produce a heating value [13].

In addition, the elements $\mathrm{C}, \mathrm{H}$, and $\mathrm{O}$ are the main elements of biomass that play a role. The physical and chemical properties of biomass depend on the structure and chemical elements and affect the characteristics of combustion and thermal utilization [14]. Higher content of carbon and hydrogen causes a higher heating value, while higher oxygen content will decrease the heating value. The content of these elements will have an impact on the resulting combustion temperature.

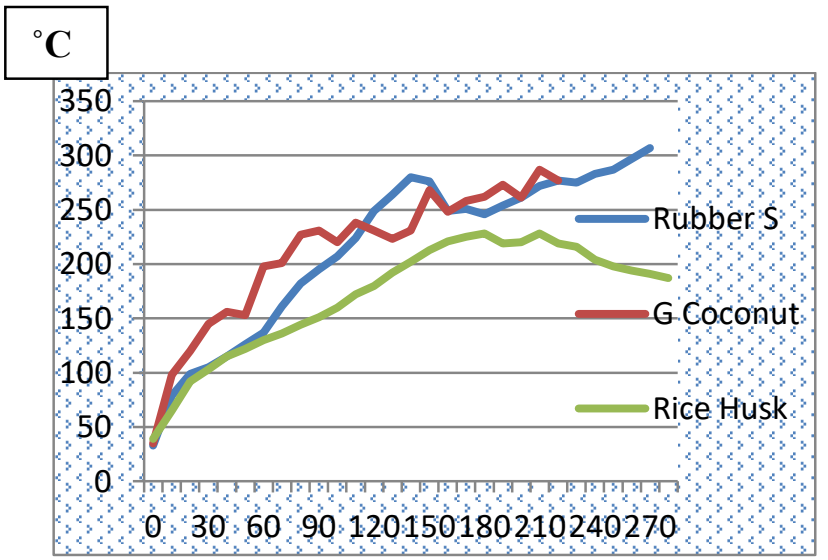

Figure 2. Temperature and combustion time of various biomass.
For rice husks, due to the shape of the grains so they are arranged tightly and the smallest heating value of $3626,482 \mathrm{Cal} / \mathrm{gr}$, the combustion temperature is also small at $219^{\circ} \mathrm{C}$ and the combustion energy is also small at $3083.54 \mathrm{~kJ}$ as shown in figure 3 . The first process in combustion is the evaporation of existing water, then volatile components are removed at temperatures of $100^{\circ} \mathrm{C}$ to $600^{\circ} \mathrm{C}[15]$. The combustion reaction involves combining the charcoal from the husk with oxygen to form the water. Rice husk contains approximately $1.54 \%$ hydrogen, $1.33 \%$ carbon (carbon) and $33.64 \%$ oxygen.

For green coconut husk, the combustion temperature is quite high at $277^{\circ} \mathrm{C}$ but a short time is 225 minutes due to the coconut husk has a large and fibrous shape so that it is easy and quick to burn and the heating value is quite high. The temperature of green coconut husk increases every minute because it is flammable and the combustion time is faster because of the soft and fibrous texture so it is flammable and quickly exhausted. The burning energy of green coconut husk is higher at $4520.88 \mathrm{~kJ}$ in picture 3 . Green coconut husk has a low bulk density with high porosity and volatile matter. Bulk porosity with a lot of empty space, causing green coconut husk will be more flammable, due to the mixing of combustible material with air becomes better. The average start-up time in various types of biomass hot start phase is faster than the cold start phase. This is possible due to the heat transfer to the fuel and the combustion process occurs more quickly in the hot start phase than the cold start phase. High volatile matter allows fuel to be quickly ignited into gas.

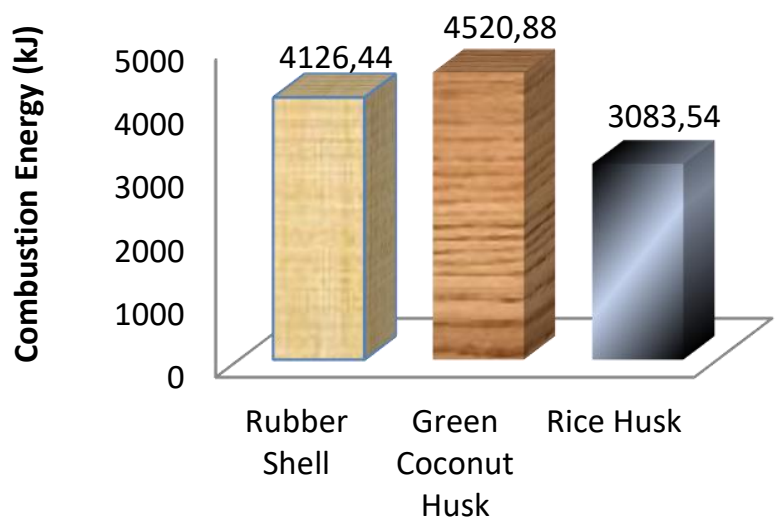

Figure 3. Diagram of Combustion energy for each biomass.

The magnitude of volatile matter in biomass increases the energy content in the biomass (the heating value), and the resulting flame temperature becomes larger [14]. The amount of volatile matter indicates more content of hydrocarbon compounds can be burned as biomass. The longer the combustion, the more 
volatile matter evaporates, with an indicator the higher the temperature of the flame generated.

Operating time is significantly affected by mass, type and size variation in fuel or biomass. The amount of weight, size, bulk density, and porosity affect the operating time in this stove. Small bulk density will have a large porosity making biomass more flammable. Due to a lot of air will come in and the combustion will be better. Mentioned the smaller fuel particle size, the bigger contact area between biomass and oxygen, resulting in a fairly high combustion reaction [16].

Yield is one of the important parameters to determine the results of a bio-charcoal process in this research produced through the pyrolysis combustion process in the pyrolysis reactor. Based on the results obtained in figure 4 , the rubber shell charcoal generate highestr yield of charcoal of $47.9 \%$ then $44.8 \%$ rice husk and the lowest one is green coconut husk $42.9 \%$, this is due to the harder biomass the more charcoal produced and less ash, like a rubber shell that has a hard texture. Conversely softer biomass, the less charcoal, and ash, like green coconut husk with a fibrous and soft texture. The yield of bio charcoal in this research is better when compared to [17] research, namely at pyrolysis temperature of $300^{\circ} \mathrm{C}-500^{\circ} \mathrm{C}$, the results of sludge cake charcoal only reached $28 \%$, while the yield of charcoal reject pulp was smaller at only $8 \%$.

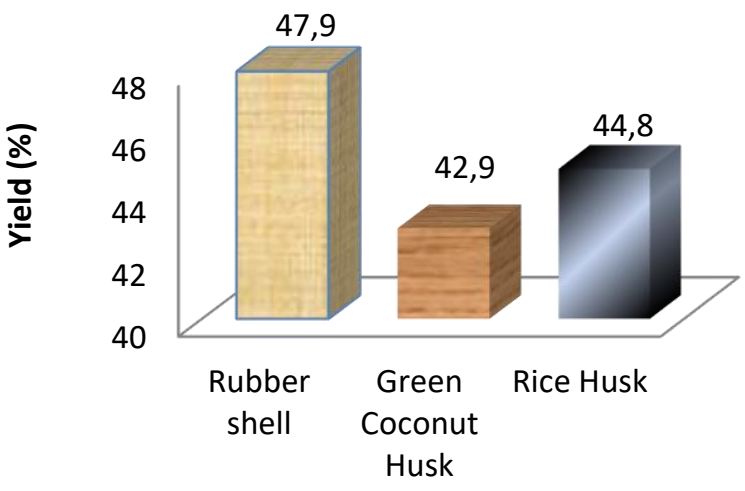

Figure 4. The yield of bio-Charcoal for each biomass

The charcoal yield is affected by temperature, residence time and water content bound in the pyrolysis media, so the charcoal yield will drop drastically on the increase in residence time, pyrolysis temperature and the presence of bound water content in the pyrolysis media [18]. Mentioned in high-temperature pyrolysis a high heat transfer occurs which causes rapid devolatilization and encourages more formation of tar and gas and causes reduced charcoal production [17]. Otherwise, process in low-temperature pyrolysis low heat transfer occurs so that the vapors formed from the evaporation of bound water will interact with charcoal, thereby reducing the yield of charcoal. The longer the residence time, the more components of the flying substance are degraded. The decrease in the amount of charcoal with an increase in temperature is mainly due to better biomass conversion caused by the primary pyrolysis reaction.

The results of the liquid smoke yield per biomass as shown in Figure 5, it appears that the rubber shell produces the smallest value of $5.04 \%$, compared to $9.74 \%$ rice husk biomass. This can be affected by many things such as temperature, time, heating rate, particle size, type and composition of biomass material. Even at the same pyrolysis temperature. The volume of liquid smokes obtained is less and this is related to the design of the pyrolysis used.

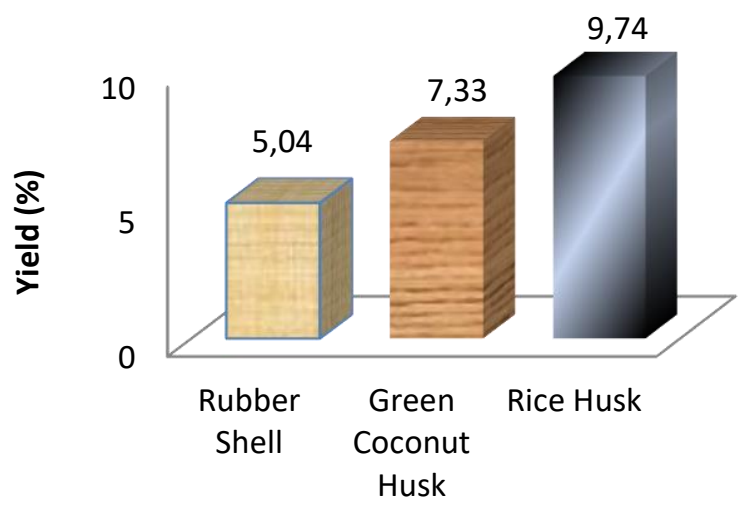

Figure 5. Liquid smoke yield for each biomass

That the results of analysis of variance showed that the interaction of temperature treatment and pyrolysis time did not significantly affect the yield of liquid smokes produced, but the single factor of temperature and pyrolysis time had a very significant effect on the yield of liquid smokes, then the single factor was continued with the DMRT test [19].

Loss of weight (loss) is the number of raw materials that are not converted into products (fumes condensate) [20]. Weight loss can also be in the form of gas that is not condensed and slowly evaporates after passing through a condenser such as $\mathrm{CO}, \mathrm{CH}_{4}, \mathrm{CO}_{2}$ dan $\mathrm{H}_{2}$. In addition, weight loss in the pyrolysis process can also be in the form of crust left in the reactor or in the condenser. Weight loss during the pyrolysis process in this study ranged from $14,65 \pm 0,90 \%$. The reactor plays an important role in producing liquid smokes yields, such as the presence of fumes leakage or lack of flame, the condenser pipe used also has an important role [21].

Pirolysis at high temperatures and heating for a long time will cause less formation of liquid smokes due to the temperature in the cooling water is increasing so that the fumes produced are not completely condensed. The condensation process will take place optimally if the water in the cooling system continuously flows so that the temperature in the system does not increase. 
Liquid smokes resulting from the pyrolysis process of wood material can be produced maximally if the condensation process occurs perfectly [22].

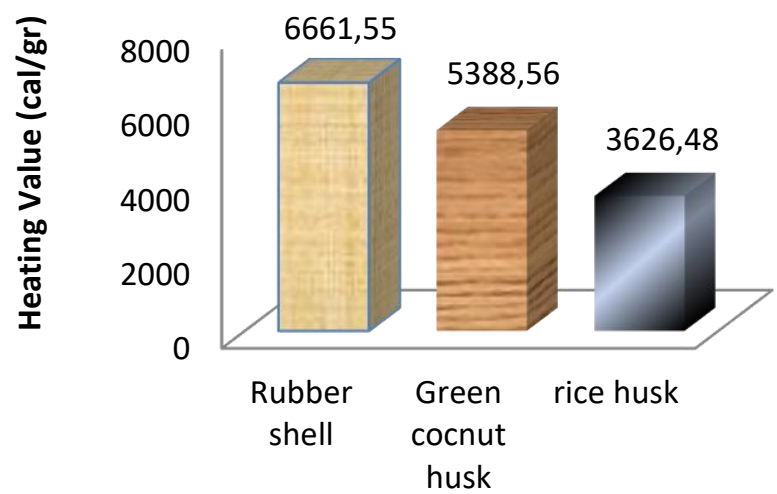

Figure 6. Heating value of bio-charcoal for each biomass

Carbon content is the amount of pure carbon contained in charcoal. higher temperatures in the carbonization process significantly affect the quality of charcoal. Based on the results of chemical lab testing table 3 shows that the highest heating value of biomass from rubber shells is 6661.549 $\mathrm{cal} / \mathrm{gr}$. according to the highest temperature of $307^{\circ} \mathrm{C}$ and the longest time is 270 minutes. Then Followed by green coconut husk the heating value was decreased for $5388,561 \mathrm{Cal} / \mathrm{gr}$ and the smallest is rice husk with 3626,482 heating value and that was appropriate towards temperature and the combustion time. This is caused by high temperature and carbonation time resulting in damage to carbon plates and due to excessive oxidation. Increased oxidation energy, both by high temperature or oxidizing gases will cause pore wall damage so that the surface area of the pore wall will decrease and carbon content obtained is smaller. This is in accordance with [23], the highest carbon content obtained was $41,3 \%$ at $400^{\circ} \mathrm{C}$ with 120 minutes of carbonization time. An increase in the heating value of charcoal in accordance with an increase in a pyrolysis temperature thereby increase the evaporation of volatile matter resulting in a decrease in water content and leaving carbon in the charcoal so that causes an increased heating value in that charcoal.

\section{CONCLUSIONS}

Based on the research results it can be concluded as follows is the result of liquid smoke from rubber shell is 240 $\mathrm{gr}$, the result of liquid smoke from green coconut husk is 300 $\mathrm{gr}$, and rice husk is $284 \mathrm{gr}$. The result of rubber shell bio charcoal is $2,3 \mathrm{~kg}$, green coconut husk bio-charcoal is $1,8 \mathrm{~kg}$ and bio-charcoal of rice husk is $1,3 \mathrm{~kg}$. The heating value of bio-charcoal from rubber shells is $6661,55 \mathrm{cal} / \mathrm{gr}$, the heating value of bio-charcoal from coconut husk is $5388,56 \mathrm{cal} / \mathrm{gr}$, and the heating value of bio-charcoal from rice husk is $3626,48 \mathrm{cal} / \mathrm{gr}$. The Combustion energy of rubber shells is $4126 \mathrm{~kJ}$, combustion energy of green coconut husk is 4520,88 $\mathrm{kJ}$, and the combustion energy of rice husk is $3083,54 \mathrm{~kJ}$.

\section{ACKNOWLEDGMENT}

Authors wish to acknowledge and thank the Directorate of Research and Community Service The Ministry of Research Technology and Higher Education of the Republic of Indonesia that was supported this research in The National Strategy Research Program 2019. Author also thank to Rector of Muhammadiyah Metro University and The Head of Institute for Research and Community Services of Muhammadiyah Metro University.

\section{REFERENCES}

[1] S. Sulaiman, "Biomassa Gasifikasi. Makalah Pelatihan Biomass Energi," Baristand Industri, Surabaya, 2009.

[2] O. Paris, C. Zollfrank and G. A. Zickler, "Decomposition and carbonization of wood biopolymer microstructural study of wood pyrolisis," Carbon, vol. 43, pp. 53-66, 2005.

[3] C. D. Blasi, "Modelling chemical and phisycal processes of wood and biomassa pirolisis," Progress in Energy and combustion science, vol. 34, pp. 47-99, 2008.

[4] F. Rodriguez-Reinoso, "The role of carbon materials in heterogeneous catalysis," Carbon, vol. 36, pp. 159$175,1998$.

[5] B. Kamulyan, "Isolasi Bahan Bakar (Biofuels) dari Tar-asap cair hasil pirolisis tempurung kelapa," Universitas Gajah Mada, Jogyakarta, 2008.

[6] I. Fatimah and J. Nugraha, "Identifikasi hasil pirolisis serbuk kayu jati menggunakan principal component analysis," Jurnal Ilmu Dasar, vol. 4, pp. 41-47, 2005.

[7] H. Heyerdahl and G. Geoffrey, Distributed Biomass Conversion, Oslo: Norwegian University, 2006.

[8] N. Vivas, C. Absalon and P. Soulie, "Pyrolysis-gas chromatography/ mass spectrometry of Quercus sp wood," Journal of Analytical and Applied Pyrolysis, vol. 75, pp. 181-193, 2006.

[9] N. Montazeri, A. C. M. Oliveira and et.al, "Chemical characterization of commercial liquid smoke products," Food Science and Nutrition, vol. 1, pp. 102115, 2013.

[10] J. P. Girrard, Smoking in Technology of Meat Products, New York: Clermont Ferrand Ellis Horwood, 1992. 
[11] A. Nur, P. W. A. Descessar and et.al, "Pengaruh Ukuran Bahan Bakar Terhadap Hasil Gas Reaktor Bubbling Fluidized Bed Gasifier," in Urecol Proceeding Seminar Nasional, 2017.

[12] Onu, F. Sudarja and M. B. N. Rahman, "Pengukuran Nilai Kalor Bahan Bakar Briket Arang Kombinasi Cankang Pala (Myristica Fragan Houtt) dan Limbah Sawit (Elaeis Guenensis)," in Seminar Nasional Teknik Mesin UMY, Yogyakarta, 2010.

[13] Suhartono, Gasela and Fitria, "Kajian Kinerja Kompor Limbah Biomassa Padat Skala Industri Rumah Tangga," in Seminar Nasional Teknik Kimia Kejuangan Yogyakarta, Yogyakarta, 2018.

[14] S. Nugraha, "Pemanfaatan Sekam sebagai Bahan Bakar Murah," Informasi Ringkas Balai Besar Penelitian dan Bank Pengetahuan Padi Indonesia, Jakarta, 2008.

[15]Z. Luo, S. Wang and K. Cen, "A model of wood flash pyrolysis in fluidized bed reactor," Renewable Energy, vol. 30, pp. 377-392, 2005.

[16] Syamsudin and S. Purwati, "Pirolisis Isotermal Sludge Cake Dan Pulp Reject Pabrik Pulp Kraft," Jurnal Selulosa, vol. 6, p. $71-82,2016$.

[17] Y. H, Y. R, C. H, L. D, L. D and Z. C, "Pyrolisis of palm oil waste for enhance production of hydrogen rich ga," Fuel Processing Technology, vol. 87, pp. 935-942, 2006.

[18] P. Young-Hun, K. Jinsoo., K. Seung-So and et.al, "Pyrolisis characteristic and kinetics of oak tree using thermogravimetric analyzer and microtubing reactor," Bioresource Technology, vol. 100, pp. 400-405, 2008.

[19] Fadillah, Haris, Alfiarty and Alivia., "The Influence Of Pyrolysis Temperature And Time To The Yield And Quality of Rubber Fruit (Hevea brasiliensis) Shell Liquid Smoke," in Prosiding pada Seminar Nasional Teknik Kimia “Kejuangan”, 2015.

[20] Ratnawati and S. Hartanto, "Pengaruh Suhu Pirolisis Cangkang Sawit Terhadap Kuantitas dan Kualitas Asap Cair," Jurnal Akreditasi LIPI, vol. 12, pp. 7-11, 2010.

[21] M. Sari, Noor and F. Mahdie, "Rendemen Arang Sekam Dan Kualitas Asap Cair Sekam Padi," Jurnal Hutan Tropis, vol. 6, pp. 260-266, 2015.

[22]A. Demirbas, "Pyrolysis of ground beech wood in irregular heating rate conditions," Journal of Analytical Applied and Pyrolysis, vol. 73, pp. 260-266, 2005.

[23] Siahaan, Satriyani, Hutapea and Melvha, "Penentuan Kondisi Optimum Suhu Dan Waktu Karbonisasi Pada Pembuatan Arang Dari Sekam Padi," Jurnal Teknik Kimia, vol. 2, pp. 26-30, 2013. 